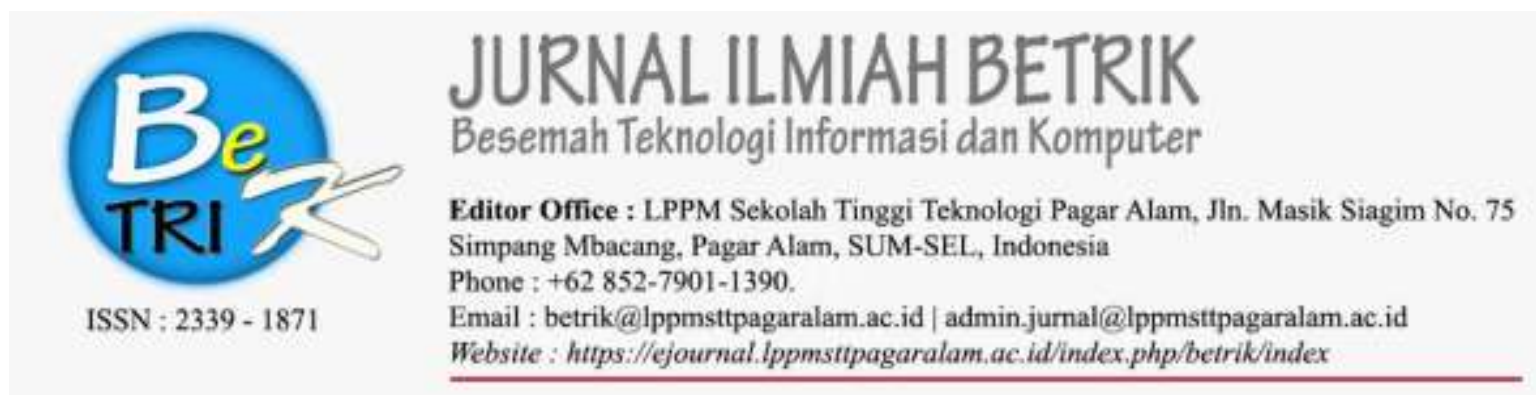

\title{
Rancang Bangun Pengolahan Data Pelanggan Pada UPTD Pengolahan Air Minum Kota Pagar Alam Dengan PHP
}

\author{
Buhori Muslim \\ Dosen Sekolah Tinggi Teknologi Pagar Alam \\ Jalan Masik Siagim No.75 Simpang Mbacang Kec.Dempo Tengah Kota Pagar Alam \\ Sur-el: buhorimuslim@sttpagaralam.ac.id
}

\begin{abstract}
The purpose of this study is the Build website at UPTD Pagar Alam drinking water treatment in order to help users get information about krgiatan and processing the data necessary for the treatment of drinking water UPTD Pagar Alam. With her website at drinking water treatment UPTD Pagar Alam is expected to provide fast, precise and accurate for those in need. UPTD drinking water treatment Pagar Alam despite the availability of the Internet however, the unavailability of a website to facilitate the search of information about drinking water treatment UPTD Pagar Alam. Systems Development Method used method of Web Engineering with stage-phases: Custumer Communication, Planning, Modeling, Contruction and Deployment. Design using UML and Programming using PHP. The results of the research the availability of drinking water treatment UPTD Website Pagar Alam Alam can be accessed by the user wanted to know information UPTD drinking water treatment Pagar Alam.
\end{abstract}

Keywords: Website, Design, Web Engineering, UML and PHP

\begin{abstract}
Abstrak: Tujuan dari penelitian ini adalah Membangun website pada UPTD pengolahan air minum Pagar Alam guna membantu user mendapatkan informasi tentang krgiatan serta pengolahan data-data yang diperlukan didalam UPTD pengolahan air minum Kota Pagar Alam. Dengan di buatnya websiteUPTD pengolahan air minum Kota Pagar Alam di harapkan dapat memberikan informasi yang cepat, tepat dan akurat bagi pihak yang membutuhkan. UPTD pengolahan air minum Kota Pagar Alam walaupun sudah tersedianya jaringan internet akan tetapi, belum tersedianya website yang dapat mempermudah pencarian informasi tentang UPTD pengolahan air minum Kota Pagar Alam. Metode Pengembangan Sistem yang digunakan adalah metode Web Engineering dengan tahap-tahapan : Custumer Communication, Planning, Modeling, Contruction dan Deployment. Perancangan menggunakan UML dan Pemrograman menggunakan PHP. Hasil dari penelitian tersedianyaWebsiteUPTD pengolahan air minum Kota Pagar Alam Alam ini dapat di akses oleh user yang ingin mengetahui informasiUPTD pengolahan air minum Kota Pagar Alam.
\end{abstract}

Kata Kunci: Website, Rancang Bangun, Web Engineering, UML dan PHP 


\section{PENDAHULUAN}

Di era yang serba canggih sekarang ini, manusia dituntut berwawasan global, apa lagi saat ini semua pekerjaan harus serba cepat, tepat dan akurat. Oleh karena itu diperlukan alat bantu seperti komputer, karena pada masa sekarang ini komputer sudah tidak asing lagi di kalangan pelajar dan masyarakat umum. Sesuai dengan pengertian komputer merupakan serangkaian alat elektronik yang saling bekerja sama dan dapat menerima data, mengolah data serta memberikan informasi yang terkoordinasi di bawah kontrol program yang tersimpan di dalam memorinya. Komputer juga bisa bekerja secara elektronik yang dapat membantu manusia dalam pemecahan masalah seperti logika, perhitungan, aritmatika dan sebagainya.

Oleh karena itu peralatan komputer sangat dibutuhkan oleh lembaga atau organisasi agar dapat menjalankan tugasnya secara efektif dan efisien. Demikian juga halnya dengan UPTD Pengolahan Air Minum Kota Pagar Alam, tentunya banyak data-data yang harus diolah dengan sistem komputerisasi baik dilingkungan kantor maupun di luar kantor tersebut. UPTD Pengolahan Air Minum Kota Pagar Alam merupakan kantor pelayanan masyarakat yang bergerak di bidang pengadaan air bersih untuk masyarakat Kota Pagar Alam yang membutuhkan air bersih.

Dalam kinerjanya UPTD Pengolahan Air Minum Kota Pagar Alam setiap akhir bulannya mengolah data pelanggan, yang mana sistem tersebut dibuat dengan cara menggunakan sistem komputerisasi, akan tetapi proses pengolahan datanya masih menggunakan Microshoft word dan Microshoft excel, sehingga proses pengolahan datanya masih belum efektif dan efesien.

Rumusan masalah yang akan dibahas dalam penelitian ini adalah bagaimana cara membuat Rancang Bangun Pengolahan Data Pelanggan Pada UPTD Pengolahan Air Minum Kota Pagar Alam dengan menggunakan Bahasa Pemrograman PHP?

Adapun Tujuan dari penelitian yang dilakukan oleh peneliti adalah sebagai berikut

a. Untuk membuat Rancang Bangun Pengolahan Data Pelanggan dengan menggunakan Bahasa pemrograman PHP.

b. Menerapkan Rancang Bangun Pengolahan Data Pelanggan dengan menggunakan Bahasa Pemrograman PHP pada UPTD Pengolahan Air Minum Kota Pagar Alam yang lebih efektif dan lebih efesien dari sistem sebelumnya.

\section{METODOLOGI PENELITIAN}

\subsection{Metode Pengembangan Sistem}

Menurut (Pressman 2005:502)Metode pengembangan adalah menyusun suatu sistem yang baru untuk menggantikan sistem yang lama secara keseluruhan atau memperbaiki sistem yang telah berjalan. Dalam pengembangan sistem ini metode pengembangan menggunakan metode web engineering, yaitu suatu model rekayasa perangkat lunak, yang digunakan untuk pengembangan aplikasi berbasis web atau lebih lanjutnya proses yang digunakan untuk menciptakan aplikasi web yang berkualitas tinggi. Rekayasa web mengadaptasi rekayasa 
perangkat lunak dalam hal konsep dasar yang menekankan pada aktifitas teknis dan manajemen. Desain sebuah aplikasi web menekankan pada desain grafis, desain informasi, teori hypertext, desain sistem dan pemrograman.

Metode pengembangan web engineering memiliki 5 (lima) tahapan yaitu :

\subsubsection{Customer Communication}

Komunikasi dalam hal ini terutama terkosentrasi antara Pelanggan dan UPTD PAM Kota Pagar Alam dengan User melalui admin, yang dihubungkan dengan sistem aplikasi, dan sistem akan mendefinisikan hal-hal apa saja yang termuat di dalam aplikasi web, misalnya pengguna web yang akan dibangun, database yang digunakan, integrasi antara web yang akan dibangun dengan situasi sistem yang sedang berjalan seperti hubungan antara Pelanggan dan UPTD PAM Kota Pagar Alam dengan Admin, dan melakukan pengumpulan informasi tentang hal-hal yang akan dimuat dalam web yang melibatkan semua pengguna.

\subsubsection{Planning}

Pengerjaan proyek pengembangan aplikasi web dilakukan dengan membuat perencanaan yang terdiri dari pendefinisian pekerjaan dan membuat target waktu pekerjaan. Pendefinisian pekerjaan yang di lakukan adalah dengan melakukan kegiatan sebagai berikut :

1. Melakukan penelitian terhadap tempat yang akan diteliti.

2. Mengidentifikasi setiap masalah yang terjadi.

3. Mengumpulkan data-data yang berhubungan dengan sistem yang akan dibuat
4. Membuat perancangan sistem.

5. Mengimplementasikan hasil dari rancangan sistem.

\subsubsection{Modelling}

Tujuan dari aktivitas ini adalah untuk menjelaskan hal-hal apa saja yang memang diperlukan / dibutuhkan pada aplikasi yang akan dibangun dan solusi yang ditawarkan yang diharapkan dapat menjawab apa yang tersirat dari hasil-hasil analisa dan pengumpulan data.

\subsubsection{Construction}

Pembangunan aplikasi web memadukan antara perkembangan teknologi dengan toolspengembangan web yang telah ada, artinya memilih tools yang efektif namun tetap dapat menyesuaikan dengan teknologi yang berkembang saat ini.

\subsubsection{Deployment}

Aplikasi web diciptakan untuk dapat berguna bagi kebutuhan pekerjaan, dapat dioperasikan oleh end-user, kemudian dilakukan evaluasi secara berkala, member masukanmasukan kepada team pengembang dan apabila diperlukan akan dilakukan modifikasi pada aplikasi web tersebut.

Alasan peneliti menggunakan metode web engineering ini, karena metode ini cukup efektif sebagai paradigma dalam rekayasa perangkat lunak, karena kebutuhan dan aturan yang jelas dan dalam pembuatan perangkat lunak bisa dilakukan secara cepat dan memungkinkan untuk merubah kembali perangkat lunak agar sesuai dengan kebutuhan pengguna.

\subsection{Rancang Bangun}

Rancang Bangun adalah tahap dari setelah analisis dari siklus pengembangan sistem 
yang merupakan pendefinisian dari kebutuhankebutuhan fungsional, serta menggambarkan bagaimana suatu sistem di bentuk yang dapat berupa penggambaran, perencanaan dan pembuatan sketsa atau pengaturan dari beberapa elemen yang terpisah kedalam satu kesatuan yang utuh dan berfungsi, termasuk menyangkut mengkonfigurasikan dari komponen-komponen perangkat keras dan perangkat lunak dari suatu sistem.(Jogiyanto 2005:197).

\subsubsection{Pengertian Perancangan Perancangan Informasi} dan

Menurut (Jogiyanto, 2001:62) Perancangan merupakan kegiatan untuk membentuk membuat sketsa struktur kegiatan atau pekerjaan dari suatu analisis kedalam suatu perencanaan untuk dapat diterapkan dalam suatu bentuk nyata.

Pengertian perancangan sistem informasi yang dikemukan oleh para ahli salah satunya menjelaskan perancangan sistem informasi dapat diuraikan sebagai berikut: perancangan sistem informasi adalah suatu fase yang diawali dengan evaluasi atas alternatif rancangan sistem yang diikuti dengan penyiapan spesipikasi rancangan yang berorientasi kepada pemakai tertentu yang diakhiri dengan pengajuan rancangan pada manajemen puncak. (Mulyadi, 1997:35).

\subsubsection{Pengertian Data}

Data adalah bahan baku informasi yang belum jadi sehingga yang di definisikan sebagai kelompok simbol-simbol, hurup-hurup, angka- angka yang mewakili kualitas, tindakan, benda dan sebagainya.(Jogiyanto, 2005:68)

1.

ata terdiri dari kumpulan karakter numeric atau alpanumeric yang memberikan arti tertentu.

2.

ata merupakan fakta, dokumen atau surat keterangan yang dapat diperoleh dari sumber asli

3. Data tidak dapat dipakai langsung untuk pengambilan keputusan (bahan mentah) data dapat dimanfaatkan setelah komputer mengolahnya menjadi informasi

\subsubsection{Pengertian Pelanggan}

Pelanggan adalah seseorang atau sekelompok orang yang menjadi pemakai atau pembeli secara terus menerus terhadap suatu obyek yang dipakai atau dibeli untuk digunakan dalam kebutuhan sehari-hari (Darmawijaya 2004:21).

\subsubsection{Unified Modelling Language (UML)}

UML (Unified Modeling Language) adalah sebuah bahasa yang telah menjadi standar dalam industri untuk visualisasi, merancang dan mendokumentasikan sistem piranti lunak. (Yuni Sugiarti: 2013:34).

\section{Use Case Diagram}

Use case diagram menggambarkan fungsionalitas yang diharapkan dari sebuah sistem. Yang ditekankan adalah "apa" yang diperbuat sistem, dan bukan "bagaimana". Sebuah Use Casemerepresentasikan sebuah interaksi antara aktor dengan sistem. Use case merupakan sebuah pekerjaan tertentu, 
misalnya login ke sistem, meng-create sebuah daftar pegawai, dan sebagainya. Seorang/sebuah aktor adalah sebuah entitas manusia atau mesin yang berinteraksi dengan sistem untuk melakukan pekerjaan-pekerjaan tertentu.

\section{Class Diagram}

Class Diagram adalah sebuah spesifikasi yang jika diinstansiasi akan menghasilkan sebuah objek dan merupakan inti dari pengembangan dan desain berorientasi objek. Class menggambarkan keadaan (atribut/properti) suatu sistem, sekaligus menawarkan layanan untuk memanipulasi keadaan tersebut (metoda/fungsi).

\section{Statechart Diagram}

Statechart diagram menggambarkan transisi dan perubahan keadaan (dari satu state ke state lainnya) suatu objek pada sistem sebagai akibat dari stimuli yang diterima. Pada umumnya statechart diagram menggambarkan class tertentu (satu class dapat memiliki lebih dari satu statechart diagram).

\section{Actifity Diagram}

Activity diagrams menggambarkan berbagai alir aktivitas dalam sistem yang sedang dirancang, bagaimana masing-masing alir berawal, decision yang mungkin terjadi, dan bagaimana mereka berakhir. Activity diagram juga dapat menggambarkan proses paralel yang mungkin terjadi pada beberapa eksekusi.

\section{Sequence Diagram}

Sequence diagram menggambarkan interaksi antar objek di dalam dan di sekitar sistem (termasuk pengguna, display, dan sebagainya) berupa message yang digambarkan terhadap waktu. Sequence diagram terdiri atar dimensi vertikal (waktu) dan dimensi horizontal (objek-objek yang terkait).

\section{Collaboration Diagram}

Collaboration diagram juga menggambarkan interaksi antar objek seperti sequence diagram, tetapi lebih menekankan pada peran masing-masing objek dan bukan pada waktu penyampaian message.

\section{Component Diagram}

Component diagram menggambarkan struktur dan hubungan antar komponen piranti lunak, termasuk ketergantungan (dependency) di antaranya.

\section{Deployment Diagram}

$$
\text { Deployment/physical diagram }
$$

menggambarkan detail bagaimana komponen di-deploy dalam infrastruktur sistem, di mana komponen akan terletak (pada mesin, server atau piranti keras apa), bagaimana kemampuan jaringan pada lokasi tersebut, spesifikasi server, dan hal-hal lain yang bersifat fisikal.

\subsection{Perancangan}

\subsubsection{Use Case Diagram}

Use case diagram Pengolahan Data Pelanggan Pada UPTD Pengolahan Air Minum Kota Pagar Alam, Menggambarkan interaksi antara Aktor dengan sistem yang dibuat. Dengan Use caseini dapat diketahui proses yang terjadi pada aktivitas yang berjalan. 


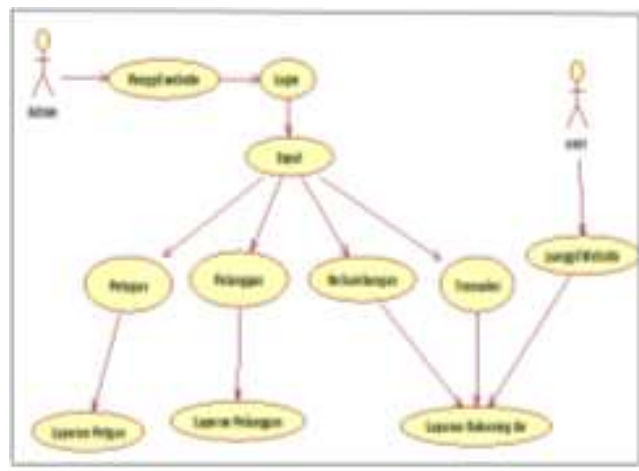

Gambar 1. Use Case Diagram

\subsubsection{Class Diagram}

Class Diagram adalah suatu diagram yang memperlihatkan atau menampilkan struktur darisebuah sistem,sistem tersebut akan menampilkan system kelas,atribut dan hubungan antara kelasketika suatu sistem telah selesai membuat diagram.Objek diagram adalah suatu diagram yang berfungsi untuk mengatur atribut,Objek danhubungan antara contoh dalam diagram,ojek diagram juga dapat menampilkan struktur model systemdalam waktu tertentu.

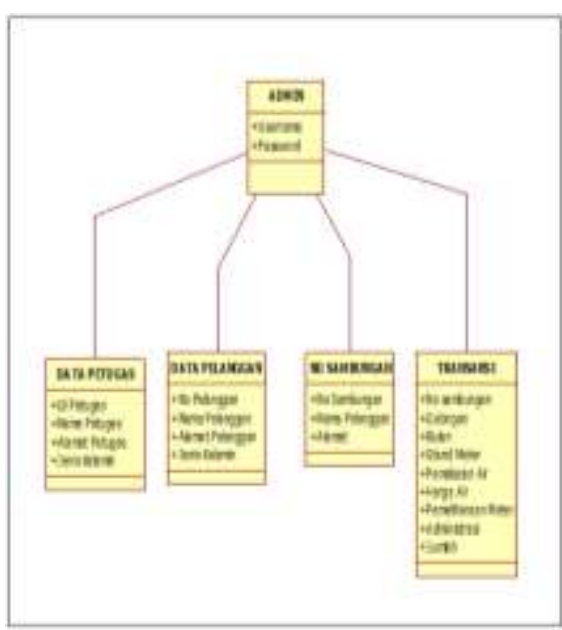

Gambar 2. Class Diagram

\subsubsection{Desain Form}

\subsubsection{Desain Menu Utama}

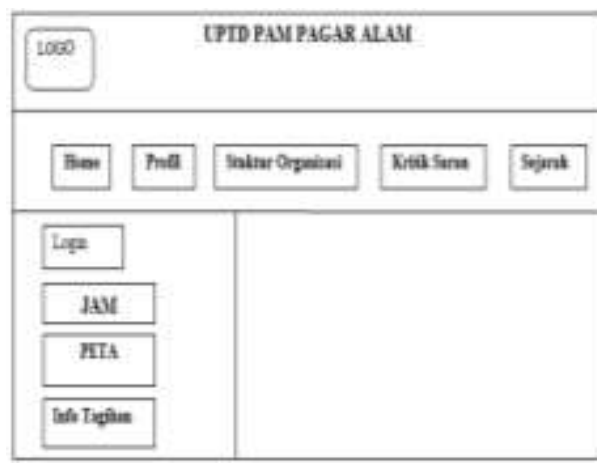

Gambar 3. Menu Utama

\subsubsection{Desain Form Pelanggan}

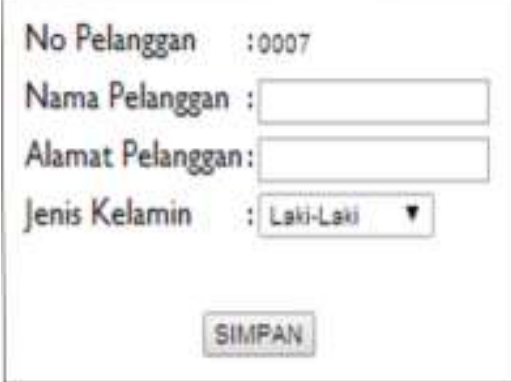

Gambar 4. Form Pelanggan

\subsubsection{Desain Form Petugas}

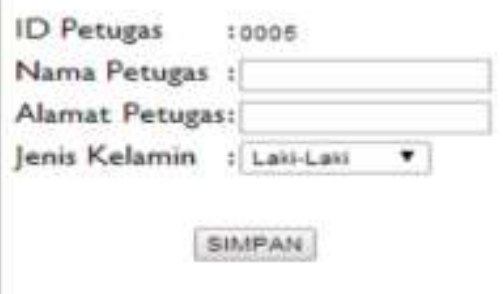

Gambar 5. Form Petugas

\subsubsection{Desain No Sambungan}

NO Sambungan :

Nama Pelanggan: adimas

Alamat

: in kact sarap -

Sirpar

Gambar 6. No Sambungan

\subsubsection{Desain Form Transaksi}




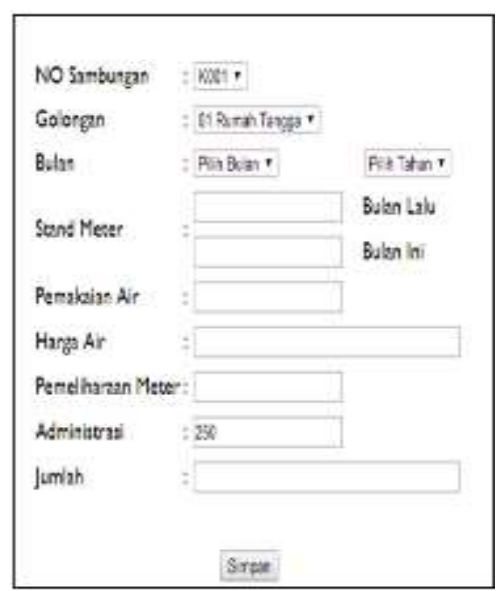

Gambar 7. Form Transaksi

\subsubsection{Desain Output Pelanggan}

\begin{tabular}{|c|c|c|c|c|c|c|c|}
\hline \multicolumn{8}{|c|}{ 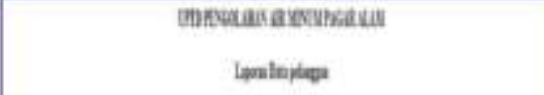 } \\
\hline $\mathrm{s}$ & lyap & lalep & burider & nitan & & $i=$ & \\
\hline 1 & Wi & Yarim & livin & $w i x$ & In & \pm & $\mathrm{m}$ \\
\hline 2 & es & $\Rightarrow$ & tisan & i.t. & lo & 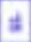 & $=$ \\
\hline 1 & iti & ad & tat & Int & ist & it & $=$ \\
\hline 4 & int & int & स्या & 4.:. & ist & it & $\mathrm{m}$ \\
\hline 1 & w & $=$ & lenging & hape & is & \pm & $=$ \\
\hline 1 & m & $=$ & jalin & $\operatorname{lin} x$ & In & It & $\Rightarrow$ \\
\hline
\end{tabular}

Gambar 8. Output Pelanggan

\subsubsection{Desain Output Petugas}

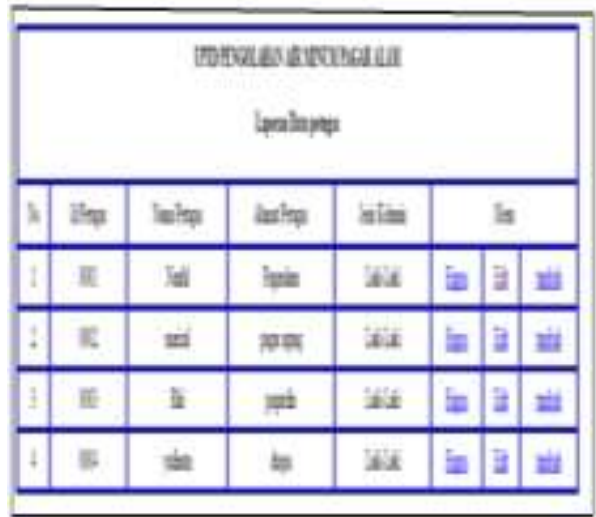

Gambar 9. Output Petugas

\subsubsection{Output Transaksi}

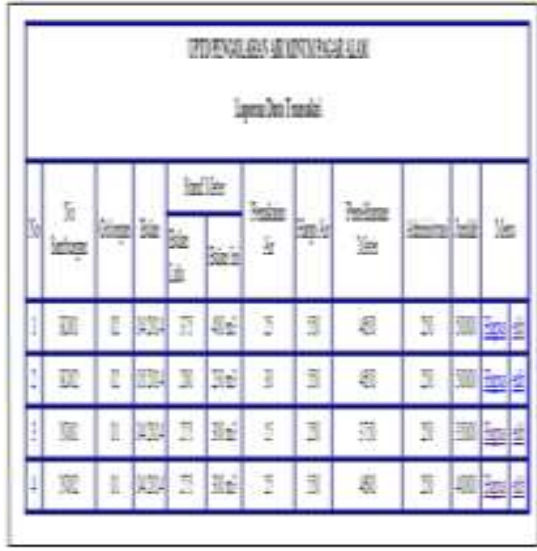

Gambar 10. Output Transaksi

\subsubsection{Output Rekening Air}

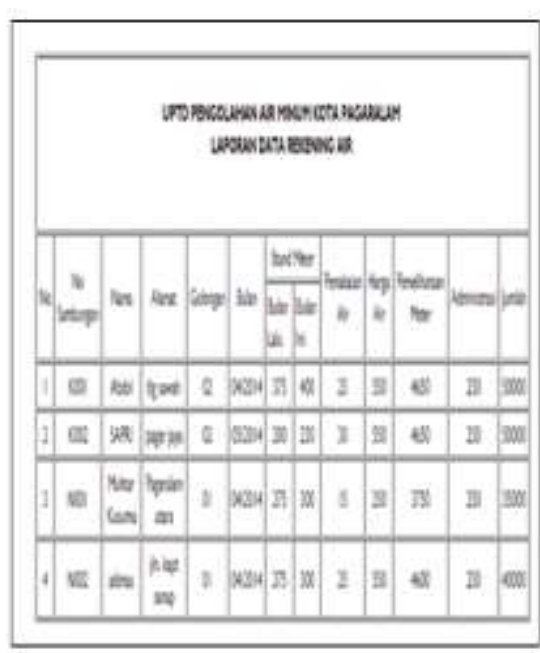

Gambar 11. Output Rekening Air

\section{c. HASIL DAN PEMBAHASAN}

\subsection{Hasil}

Menjalankan Rancang Bangun Pengolahan Data Pelanggan pada UPTD Pengolahan Air Minum Kota Pagar Alam ini secara langsung harus mempunyai web server dan database server. Di sini Penulis menggunakan xampp untuk menjalankannya. Sistem ini mempunyai halaman utama atau halaman depan yaitu index yang berfungsi sebagai halaman utama secara otomatis pada saat web ini diakses.

Berdasarkan data yang didapat pada UPTD Pengolahan Air Minum Kota Pagar Alam, 
maka dihasilkan suatu program untuk membantu dan mempermudah dalam proses informasi pelanggan yaitu Rancang Bangun Pengolahan Data Pelanggan pada UPTD Pengolahan Air Minum Kota Pagar Alam.

Rancang bangun ini terdiri dari halamanhalaman informasi, menu dan sub menu yang nantinya dijalankan dengan menggunakan browser.

\subsection{Pembahasan}

Langkah pertama untuk memulai menggunakan aplikasi ini, pastikan sudah terinstall web server dan database server, penulis menggunakan xampp untuk menjalankannya. Setelah memastikan aplikasi pendukung sudah terinstal, aktifkan halaman utama terlebih dahulu dengan membuka Browser bisa menggunakan Mozilla Firefox atau Internet Explorer.

\subsubsection{Pembahasan Halaman Utama}

Halaman utama dan Menu Login merupakan tampilan awal dari Rancang Bangun Pengolahan Data Pelanggan pada UPTD Pengolahan Air Minum Kota Pagar Alam.

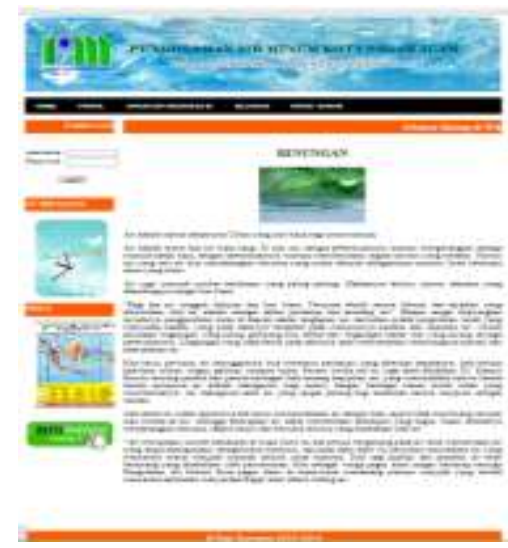

Gambar 12. Halaman Utama

\subsubsection{Halaman Input Data Pelanggan}

Halaman Input data pelanggan merupakan halaman yang bila diklik akan menampilkan form data pelanggan Setelah data pelanggan dilengkapi dan tersimpan maka otomatis akan tersimpan di data pelanggan.
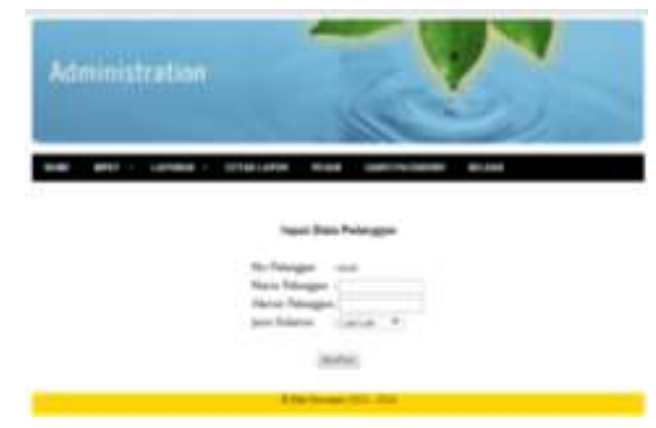

Gambar 13. Input Data Pelanggan

\subsubsection{Halaman Input Data Petugas}

Halaman Input data Petugas merupakan halaman yang bila diklik akan menampilkan form data PetugasSetelah data Petugasdilengkapi dan tersimpan maka otomatis akan tersimpan di data Petugas.
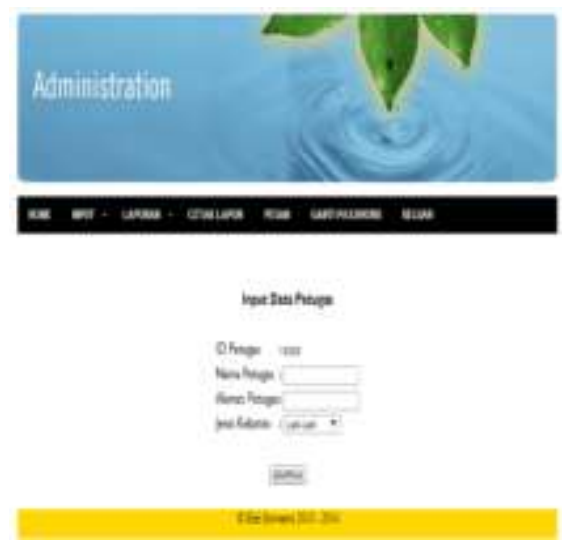

Gambar 14. Input Data Petugas

\subsubsection{Halaman Input No Sambungan}

Halaman Input data No Sambungan merupakan halaman yang bila diklik akan menampilkan form No Sambungan Setelah No 
Sambungan dilengkapi dan tersimpan maka otomatis akan tersimpan di No Sambungan.
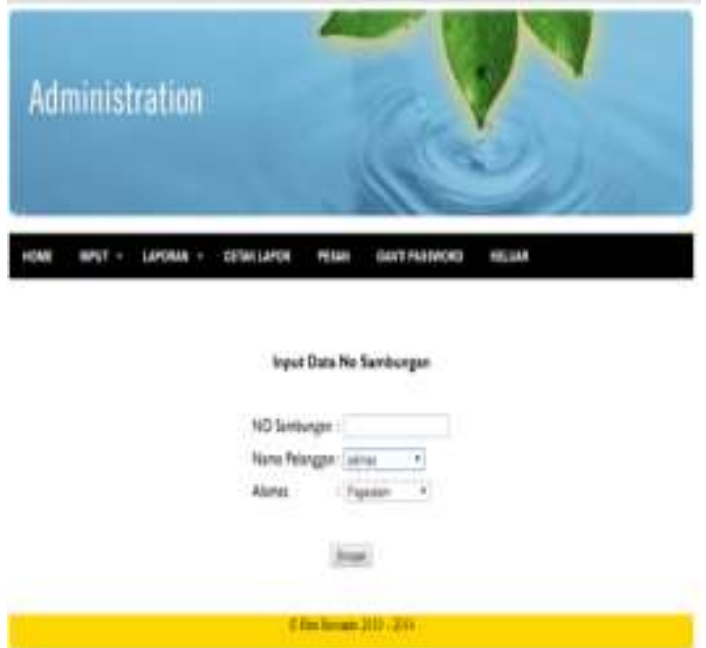

Gambar 15. Input No Sambungan

\subsubsection{Input Data Transaksi}

Halaman Input data Transaksi merupakan halaman yang bila diklik akan menampilkan form data Transaksi Setelah data Transaksi dilengkapi dan tersimpan maka otomatis akan tersimpan di laporan Transaksi.
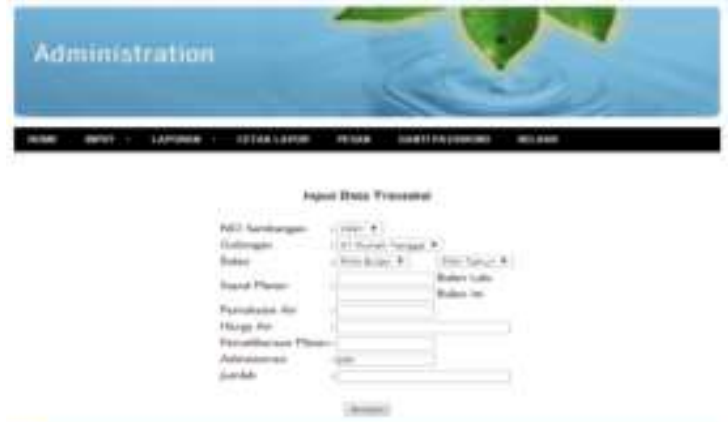

Gambar 16. Input Data Transaksi

\subsubsection{Output Pelanggan}

Halaman Ouput Pelanggan merupakan halaman laporan untuk menetahui dari penginputan data Pelanggan yang sudah di isikan.
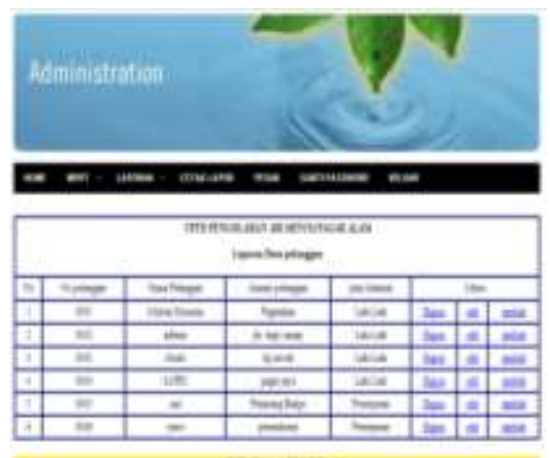

Gambar 17. Output Pelanggan

\subsubsection{Output Petugas}

Halaman Ouput Petugas merupakan halaman laporan untuk menetahui dari penginputan data Petugas yang sudah di lengkapi.
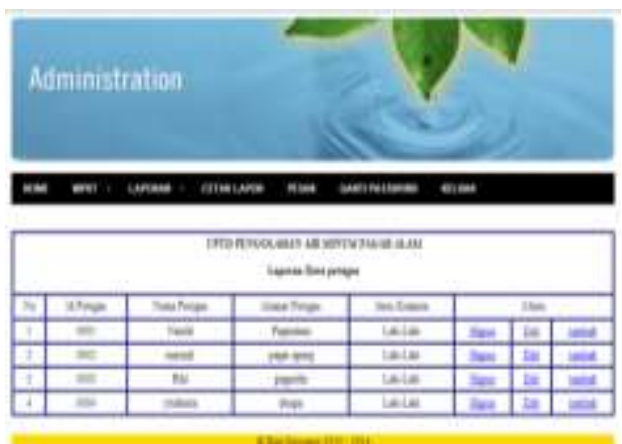

Gambar 18. Output Petugas

\subsubsection{Output Rekening Air}

Halaman Ouput Rekening Airmerupakan halaman laporan untuk mengetahui dari penginputan data Rekening Air yang sudah di lengkapi.

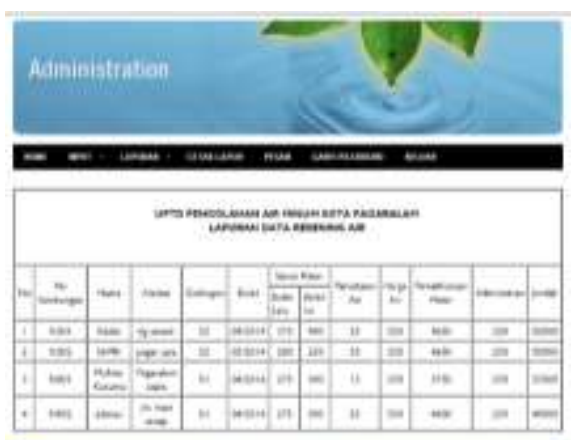

Gambar 19. Output Rekening Air 


\section{SIMPULAN}

Pada penelitian Rancang Bangun Pengolahan Data Pelanggan pada UPTD Pengolahan Air Minum Kota Pagar Alam yang dibuat dalam aplikasi program, penulis mengambil kesimpulan sebagai berikut :

1. Rancang Bangun Pengolahan Data Pelanggan pada UPTD Pengolahan Air Minum Kota Pagar Alam yang dirancang berbasis komputer dengan menggunakan Bahasa Pemrograman PHP maka dapat mempermudah dan mempercepat pekerjaan dalam mengolah data Pelanggan sehingga tidak ada lagi kesulitan dalam pemberian informasi yang dibutuhkan.

2. Rancang Bangun dengan Program PHP dapat menyimpan data-data dengan aman Serta efektif dan efisien, sehingga data-data yang tersimpan tersebut dapat dilihat kembali jika diperlukan.

\section{RUJUKAN}

Jogiyanto,HM. 2001 Analisis dan Desain Sistem Informasi.CV Andi Offset : Yogyakarta.

Nugroho,Adi 2006.Tips dan Trik Pemograman PHP 5.Ardana Media,Yogyakarta

Sukarno, Mohamad. 2006. Membangun Website Dinamis Dengan PHP-MySQL Eksa Media. Jakarta.

Priyo Utomo Eko, Akbar Ali. 2012. 1 Menit Bikin Web Sendiri dengan PHP dan jQuery. Mediakom: Yogyakarta.

Prabowo Pudjo Widodo, Herlawati. 2011. Menggunakan UML. Informatika Bandung

Kristanto, Andri.2007.Perancangan Sistem Informasi Dan Aplikasinya.

Penerbit :Gava Media,Klaten.

Preeman, SR. 2005. Rekayasa Perangkat Lunak Penerbit: CV Andi Ofset, Yogyakarta 